University of Pennsylvania Carey Law School

Penn Carey Law: Legal Scholarship Repository

Faculty Scholarship at Penn Carey Law

2020

\title{
Reviewing Inter Partes Review Five Years In: The View From University Technology Transfer Offices
}

Cynthia L. Dahl

University of Pennsylvania Carey Law School

Follow this and additional works at: https://scholarship.law.upenn.edu/faculty_scholarship

Part of the Commercial Law Commons, Contracts Commons, Entrepreneurial and Small Business Operations Commons, Higher Education Commons, Intellectual Property Law Commons, Law and Society Commons, Science and Technology Law Commons, and the Technology and Innovation Commons

\section{Repository Citation}

Dahl, Cynthia L., "Reviewing Inter Partes Review Five Years In: The View From University Technology Transfer Offices" (2020). Faculty Scholarship at Penn Carey Law. 2193.

https://scholarship.law.upenn.edu/faculty_scholarship/2193

This Book Chapter is brought to you for free and open access by Penn Carey Law: Legal Scholarship Repository. It has been accepted for inclusion in Faculty Scholarship at Penn Carey Law by an authorized administrator of Penn Carey Law: Legal Scholarship Repository. For more information, please contact PennlawIR@law.upenn.edu. 


\title{
Reviewing Inter Partes Review Five Years In: The View From University Technology Transfer Offices
}

\author{
Cynthia Laury Dahl
}

\section{Introduction}

When the America Invents Act ("AIA") was passed in $2011,{ }^{1}$ university tech transfer offices ("TTOs") were braced for big changes and potentially some fairly dire consequences. Together with other intellectual property-reliant entities, TTOs were worried that certain provisions of the AIA would directly attack the value of their patents and therefore chip away at their ability to pursue a business model based on protecting invention and licensing.

Among the most sobering of the provisions were a series of new post-grant patent review proceedings. These proceedings provided several new mechanisms for third parties to challenge already granted patents and potentially invalidate them. Designed to "weed out" weak patents that should not have been granted, these proceedings nonetheless had much broader applications. Because the proceedings were designed to be less expensive than litigation and to grant quicker yet final results, the concern was that they would become an attractive option for any third party, including potential infringers, to employ to challenge any patent, weak or strong. TTOs and other patent owners feared that the net result of these post-grant review proceedings would be to strip them of their assets, or at the very least cost them money in terms of lower patent value, uncertainty, and cost to defend.

They were partially correct. Seven years after implementation, these post-grant challenge proceedings and specifically inter partes review ("IPR") have in fact completely changed the landscape of patent litigation, as well as invalidation challenges for defendants to a patent suit. ${ }^{2}$ Not only are the numbers of IPRs voluminous, but the likelihood that a patent subject to an IPR is declared at least in part invalid is very high. ${ }^{3}$ However, although the literature seems to indicate that IPRs have had a universally chilling effect on patents, the experience of several TTO offices reveals a different story. As relayed in their own words, TTOs report that assets have thus far been mostly immune from IPR attack. This is due to a variety of reasons connected to the mission of TTOs and the nature of the intellectual property ("IP") they protect. Although the specter of post-grant challenge proceedings has in fact cost TTOs some resources through increased uncertainty and the need to adapt to the new law, the overall effect has been far milder than expected. TTOs explain that post-grant challenge proceedings in general and IPRs in

\footnotetext{
${ }^{1}$ Leahy-Smith America Invents Act (“AIA”), Pub. L. No. 112-29, 125 Stat. 284 (2011) (codified in scattered sections of 35 U.S.C.).

${ }^{2}$ Jake Berdine \& Matt Rosenberg, Creating Leverage: A Practitioner's Guide to Inter Partes Review and Its Effects on Intellectual Property License Negotiations, 44 AIPLA Q.J. 13 (Winter 2016) ("The AIA-implemented post-grant procedures fundamentally changed the landscape for defendants who are approached by patent owners seeking royalty payments for potentially invalid patents.").

${ }^{3}$ Jesse Schwartz, Supreme Court Takes Up Inter Partes Review: Is Relief In Sight?, TeCh Transfer eNews Blog (Aug. 30, 2017), https://techtransfercentral.com/2017/08/30/supreme-court-takes-up-inter-partes-review-is-relief-insight/ ("About 74\% of IPRs with final written decisions have resulted in all claims being invalidated - more than 1,200 of them so far - and about $14 \%$ have invalidated at least some claims. Only $12 \%$ have resulted in challenged patents being fully upheld.").
} 
particular have not had a significant impact on TTO licensing, nor on their traditional approach to patent filing, patent enforcement, and budgeting.

This topic is ripe for analysis. It has been seven years since the IPR procedure was enacted, and with the benefit now of two Supreme Court cases interpreting IPR, plus anecdotal information from the universities themselves, we can gather a much more accurate picture of IPR's actual effects on TTOs. ${ }^{4}$ In addition, barring large legislative changes, these effects are unlikely to shift over the next several years, although throughout this Chapter I will discuss some interesting and still evolving issues that may change the analysis slightly. Finally, although TTOs by and large have not changed their approach because of these post-grant challenge proceedings, the seven years have given some TTOs enough time to adopt a very few small shifts in policy that might be instructive for others to learn about or perhaps emulate. These small shifts are helping those TTOs to inoculate themselves from even the minor tremors caused by the possibility of post-grant challenge.

The first section of this Chapter provides a brief context for the AIA discussion, including what the AIA was designed to address, some of the changes that were implemented under the AIA, a brief description of the challenge proceedings, and why IPRs are the most relevant challenge proceeding to consider when discussing TTOs. The section also describes the methodology behind a survey I conducted of eighteen university TTOs to gather instructive anecdotal evidence presented below.

The second section contains the survey comments. It discusses why IPRs are theoretically worrisome for patent owners, but explains why IPRs have not significantly affected TTO policies and procedures about what patents they file, their licensing practices, how they enforce their patents, and their budgeting.

The final section looks forward from this point, highlighting some topics about IPRs that remain open and discussing some court cases, legislative initiatives and executive branch responses that - depending on result - may potentially have an impact on IPRs, and therefore TTO policy.

\section{AIA background and the importance of IPR}

The AIA was the first major overhaul of the patent laws in fifty years. Before its passage, conventional wisdom was that the United States Patent and Trademark Office ("USPTO") was allowing too many broadly-worded patents to issue and that enforcing such patents was stifling innovation. ${ }^{5}$ Especially large organizations in the computer/telecommunications, financial services and information technology industries were clamoring for stricter scrutiny of patents. ${ }^{6}$ Out of this history and given this perspective, Congress included a number of updates to patent law under the AIA.

Among other changes, the AIA expanded patent review proceedings, both pre- and postissuance. Of particular concern to TTOs are three new post-grant procedures available for third parties to challenge the validity of patents that have already issued: Post Grant Review

\footnotetext{
${ }^{4}$ For background information on the subject, see Robert MacWright, Three Years after the America Invents Act: Practical Effects on University Tech Transfer, 52 (3) LeS NOUVELLES - J. LICENSING EXECUTIVES Soc'Y, June 2017, https://ssrn.com/abstract=2961434; John Morgana \&Veronica Sandoval, Pacific Northwest Perspective: The Impact of the America Invents Act on Nonprofit Global Health Organizations, 9 WASH J. L. TECH. \& ARTS 177 (2013).

${ }^{5}$ Mark A. Lemley, The Unsurprising Resilience of the Patent System, 95 TEX. L. Rev. 9, 10 (2016).

${ }^{6}$ MacWright, supra note 4 at 72.
} 
("PGR") designed to "produc[e] better patents and rectif[y] improper issuances" by expediting challenges. ${ }^{10}$ However, patent holders believe the overall effect has been that third parties may more easily challenge patents, regardless of their merits, and the procedures can result in significant delay and expense for patent owners. ${ }^{11}$

Which of the above procedures is appropriate depends on the party using the challenge, the timing of challenge, the basis and type of challenge, and the subject matter of the patent. PGR can only be used for a limited time (within the first nine months after a patent issues) but any third party can use PGR to bring any evidence to bear that successfully proves invalidity on many bases, including patentable subject matter, novelty, nonobviousness, and double patenting. CBM is only applicable against business method patents and the challenger has to have been sued for infringement under the patent. However, for the lifetime of the patent (after nine months after issuance) a third party can use CBM to offer any material to invalidate the subject patent on most any basis, including patentable subject matter, novelty, nonobviousness, and double patenting. IPR is a much narrower tool in that third parties may use only other patents or written material to invalidate the subject patent under Section 102 or 103 (novelty and nonobviousness) of the Patent Act. However, similar to CBM, IPR can be used throughout the lifetime of the patent (after nine months after issuance), but the patent may cover any subject matter. The IPR proceeding can either run in parallel to an active litigation or can be instituted outside of litigation. The district court will often stay the court case waiting for the IPR result. ${ }^{12}$

Of the several new proceedings, the most relevant to TTOs is the IPR. The other two proceedings either involve subject matter that is not usually patented by TTOs (for example the "practice, administration, or management of a financial product or service," relevant to the patents subject to CBM), or are only relevant at a stage where a TTO patent is unlikely to be challenged (PGRs may only be filed during the first 9 months of an issued patent's life.) ${ }^{13}$ IPRs, on the other hand, are valid against all kinds of patents, including the life sciences and physical sciences patents that make up the bulk of the TTO docket. The IPR proceeding is also important to consider because it was the subject of two different Supreme Court rulings in the 2017-2018 term, one of which specifically affirmed it as constitutional. ${ }^{14}$

\footnotetext{
735 U.S.C. $\S \S 321-29$.

835 U.S.C. $\$ 321$.

935 U.S.C. $\S \S 311-19$. The legacy Ex Parte Re-exam procedure still remains in effect after the AIA, but among other differences, does not involve the participation of the third party and proceeds before the USPTO examiner rather than the PTAB.

${ }^{10}$ Morgan \& Sandoval, supra note 4 at 7.

${ }^{11}$ Christopher Arnold, The AIA and TTOS: How Technology Transfer Offices Can Best Handle the Changes in Patent Law Brought about by the America Invents Act, 41 J.L. \& EDUC. 417 (2012).

${ }^{12}$ A chart comparing the requirements and characteristics of each proceeding is at USPTO, https://www.uspto.gov/sites/default/files/ip/boards/...aia_trial_comparison_chart.pptx (last visited Jan. 23, 2019).

${ }^{13}$ TTOs usually file patents over very early stage technology, so their patents will likely not be commercialized and thus ripe for an IPR attack during the relevant period for a PGR.

${ }^{14}$ In Oil States Energy Services v. Greene's Energy Group, 138 S. Ct. 1365 (2018), the Supreme Court considered whether it was a violation of Article III or the seventh amendment right to a jury trial for a patent owner to lose patent rights by having its invalidity determination adjudicated in an administrative PTAB proceeding rather than an Article III court, as would happen in a patent infringement lawsuit. Ultimately the Supreme Court found the IPR proceeding constitutional because the patent rights were "public rights" derived from common law and granted by an administrative body (the USPTO), which could maintain control over the decision of whether that grant was correct. However, the Supreme Court specifically stated that it was not ruling on the possibility that IPRs might be considered unconstitutional under the Due Process clause, the Takings clause, or that IPRs might not apply
} 
The comments that provide the information in this Chapter come from telephone interviews with TTO offices performed in June and August of 2018. The subjects interviewed represented 18 TTOs, ${ }^{15}$ from large and small public and private universities, a few of which were part of a larger university system. I chose my list of interviewees to include active TTO offices, which were recommended by other interviewees as being leaders in the TTO community, that could provide a sampling of different-sized offices, different-sized universities, and both public and private institutions. Although I did not plan the survey to be exhaustive or completely inclusive, the fact that the answers were vastly consistent across the sample indicate to me that the answers to my questions are likely illustrative of the answers of many other TTOs.

In each case the employees at the TTO designated the person that I should speak to who was most knowledgeable about IPRs. Although the titles of each of the representatives I interviewed varied (as did the hierarchical structure of the TTO), generally I spoke to either the head of licensing for the TTO or to the highest ranking legal officer for the TTO. In a few cases I spoke to more than one person within the TTO - for example, when my questions crossed between the expertise of two people, or when the highest ranking person with the relevant information was relatively new to the office.

I started each interview with the same list of questions, eliciting information about the TTO's overall sense of worry about IPRs, how many IPRs the TTO had experienced (and under which circumstances), and if the TTO had changed i) filing; ii) licensing; iii) budgeting or iv) enforcement policies, procedures, or strategy because of the possibility of IPRs. I also asked if they had noticed positive or negative changes in licensing success that they could attribute to IPRs. In each case, I typed written notes during the interview, taking down answers word-forword whenever possible to allow for direct quotations. Some of the TTOs requested that their comments remain anonymous or that the statistics be reported in aggregate form. In most cases, this desire was because the TTOs had active IPR proceedings, or because they were concerned about potential licensors or potential patent challengers learning about their attitudes toward enforcement or other policies. As a result, while the statements below are direct quotations from the interviews, I do not attribute the comments to the specific TTO that made them.

\section{How are IPRs affecting TTO policies and procedures?}

\section{A. IPRs present more risk to TTOs in theory than in reality}

Across the board, the TTOs I interviewed are concerned about the effects IPRs are having on their practice. They worry that IPRs leave their assets vulnerable to attack from better funded commercial players. They fear that IPRs will tilt the license negotiation in the licensee's favor, because the licensee can threaten to file an IPR if they cannot get good license terms. And they claim that IPRs are contributing to a broad devaluing of patents across the board, because of the uncertainty they inject into the system where a patent can be declared invalid at any point in its

retroactively to patents that issued before IPRs were instituted. The other court case to consider IPRs was SAS Institute v. Iancu, 138 S. Ct. 1348 (2018), where the Supreme Court ruled that upon instituting an IPR, the USPTO was required to consider all claims that were challenged in the IPR, not just some of the claims.

${ }^{15}$ I interviewed the TTO at Arizona State University; University of California, Berkeley; University of California, Irvine; University of California, Los Angeles; Columbia University; Duke University; University of Florida; Harvard University; Johns Hopkins University; Massachusetts Institute of Technology; University of Michigan; University of Minnesota; University of Pennsylvania; Stanford University; University of Texas at Arlington; University of Wisconsin-Madison; Washington University; and Yale University. 
life. They mention that the effect of IPRs is not what was intended by Congress; that instead of empowering parties to winnow weaker patents, that IPR is being used as a litigation tactic to drive settlement and avoid having to pay for infringement. One summed up the situation by stating that IPRs "have added another burden to commercialization," and another stated that IPRs are "part of a net negative ... it really benefits everyone to have certainty on who owns patents and whether they are strong. Confusion makes it harder. All of these strategies and issues make it harder to get product out and to benefit the university."

However, curiously, the TTOs' worry has not translated into significant policy or procedural changes. Overall, the survey comments showed that the expectation of deleterious IPR effects on TTOs was much worse than the reality. In response to even perceived risk, TTOs have implemented only small changes, if any at all. In addition, for a variety of reasons IPRs have not affected TTOs' licensing success. This section will first address why TTOs might be worried about IPRs before postulating as to why the reality of IPRs does not match the expectation in the TTO setting, and therefore why TTOs can feel justified that they have made very few changes in policy.

It makes sense to be intimidated by the prospect of IPRs for a variety of reasons. First, the exposure is comprehensive. No patent is immune from IPR challenge, so long as it has been issued for at least nine months. Any third party may file an IPR, regardless of whether they are an accused infringer and regardless of whether the patent owner has filed suit.

Second, IPR procedures give distinct advantages to a patent challenger over a patent owner. It is substantially cheaper to file an IPR than for the patent owner to defend it. ${ }^{16}$ Moreover, the challenger can choose specific claims to attempt to invalidate, and estoppel only applies to claims for which the Patent Trial and Appeal Board ("PTAB") issues a written opinion. ${ }^{17}$ This means that the challenger may have several chances to challenge the patent (albeit different claims), and may in fact challenge the patent on other grounds, should the patent owner later file a patent infringement suit. ${ }^{18}$

Third, when an IPR challenge is used within the context of a litigation, the shift in the balance of power toward the patent challenger will affect the whole litigation strategy. If an IPR is timely filed, the judge in the patent infringement litigation will often stay the court case pending resolution of the IPR. Although the IPR will be resolved in no more than 12 months, this stay delays the adjudication of the infringement case and can also distract counsel and add greatly to legal fees. Although the effect of the USPTO's rulemaking changing the review standard of patent claims in the IPR context remains to be seen, IPRs have almost always invalidated at least one claim of a challenged patent, and they are commonly successful in invalidating the entire patent. ${ }^{19}$ Because of the advantages granted the challenger under an IPR,

\footnotetext{
${ }^{16}$ Neal Solomon, The Problem of Inter-Partes Review, IP WATCHDOG, Aug. 8, 2017, ("In addition to the procedural issues, IPRs introduced an asymmetric component which particularly burdens the patent holder by requiring a very expensive ten-fold higher cost to defend the patent in the PTAB relative to the alleged infringer(s) cost of initiating an IPR.").

1735 U.S.C. $\$ 315(\mathrm{e})(1)$.

${ }^{18}$ The SAS Institute case (supra note 14) and recent USPTO rule making (effective for IPRs filed after November 13, 2018) have leveled the playing field between patent holders and challengers substantially. The SAS case mandates that the PTAB review all claims challenged in the IPR, and the USPTO rule making now aligns the standard of review for claim interpretation and burden of proof used in IPRs with the standard used in the federal courts. This erases a former advantage for patent challengers, who were able to enjoy a broader claim interpretation and lower standard of proof for invalidity in $\mathrm{PTAB}$ procedures, and a narrower claim interpretation and higher standard of proof when fighting infringement in federal court.

${ }^{19}$ Schwartz, supra note 3.
} 
TTOs might think twice about enforcement, since any cease and desist letter might result in an IPR being filed. Although an IPR is always possible, it is ever more likely in the context of a patent infringement litigation.

The possibility of an IPR can be quite intimidating. However, the reality for TTOs has been quite different. The reality is that the number of IPRs being filed against TTO patents is remarkably small. In the seven years since the IPR procedure was implemented, even as other patent owners have experienced an explosion in IPR proceedings, ${ }^{20}$ half of the TTOs interviewed $(n=9)$ had not yet had their patents subject to even one IPR. ${ }^{21}$ This is especially remarkable considering not only the vast numbers of patents filed by these TTOs, but also the fact that several of the TTOs reported that they were involved in an active litigation, where an IPR challenge would be more likely. Of the half of the TTOs familiar with IPRs, many had experienced only three or fewer proceedings. And for the few TTOs that had experienced more than three IPRs, many of those IPRs were clustered into either one or two large litigations. No TTO I interviewed reported that they had had more than four active cases that involved IPRs.

The numbers may be particularly low because the chance of IPR success over TTO patents may be less than normal. TTOs must file early-stage patents both because they are covering the raw research subject matter of university labs and because TTOs often have to file patents early to beat an inventor's disclosure deadline. In order to preserve patent rights, the university may need to file patents earlier than industry counterparts, sometimes before full data gathering is complete. These early-stage patents may have enablement risk, but they are so early stage that there is also less likely to be prior art that could invalidate them. Since IPRs invalidate through prior art, the early stage of the patented matter may be an advantage.

An IPR challenge to a TTO patent is also less likely because of the TTO mission. Because TTOs focus much more on protection and licensing than on enforcement of their patents, many improbable conditions need to align for an IPR to proceed against a university patent. Patent challengers generally file IPRs in one of two scenarios: i) the patent owner has accused the challenger of infringement and the IPR is a defense; or ii) the patent presents a significant freedom to operate risk to the challenger's commercialization, and licensing is not an option. The TTOs I interviewed enforce their patents very rarely; many of them consider enforcement outside the core mission of a TTO. As a result, the likelihood of a TTO filing an infringement lawsuit and sparking an IPR is low. Likewise, for a TTO patent to meet the second condition through creating a large freedom to operate risk, the patent would either have to cover valuable seminal technology, or the technology or science would have to be developed enough that a challenger would know they could not design around it when commercializing. In addition, the challenger would have to have either been unable or unwilling to license from the TTO, and yet must be so convinced of infringement risk that they are willing to invest thousands of dollars

\footnotetext{
${ }^{20}$ Mark A. Lemley, supra note 5, at 5-6 (citing Brian Love \& Shawn Ambwani, Inter Partes Review: An Early Look at the Numbers, 81 U. CHI. L. ReV. Dialogue 93, 94-97 (2014)); see Morgan Lewis, 2018 PTAB Digest: The Latest Trends and Developments in Post-Grant Proceedings, LeXOLOGY, June 3, 2018, at 10, https://www.lexology.com/library/detail.aspx?g=0da05dd9-8d41-450a-91af-

4cae770d2ceb\&utm_source=lexology+daily+newsfeed\&utm_medium $=$ html+email+-+body+-

+ general+section\&utm_campaign=aipla $+2013+$ subscriber + daily + feed\&utm_content $=\operatorname{lexology}+$ daily + newsfeed +20 18-07-05\&utm_term.

${ }^{21}$ It is worth noting that in all the IPRs we discussed, the TTOs and their universities were on the defensive; no single TTO had launched an IPR offensively. This fits with the university mission as licensor of IP instead of commercial venture.
} 
into attacking the patent prophylactically, thereby tipping their hand to the TTO to the probable infringement risk in the process. Given the early stage of most patented university technologies, these prerequisites all occurring together is extremely unlikely.

And finally, even should a TTO face an IPR, they have two possible built-in defenses that keep the risk low. First, the TTOs of public universities may be able to completely shelter their patents from attack through a sovereign immunity defense. And second, most TTOs-from both public and private universities - face little or no risk of funding the IPR defense in all but the most unusual of conditions.

Because the 11th Amendment protects states from federal suit, if IPRs are considered suits and state-run universities are considered arms of the state, public universities can invoke the defense of sovereign immunity to avoid IPRs completely. Two recent cases before the PTAB, namely Covidien LP v. Univ. of Fl. Research Foundation Inc. ${ }^{22}$ and NeoChord, Inc. v. Univ. of $M d$., Baltimore, ${ }^{23}$ each established that sovereign immunity properly shielded the university patents from IPR, even though (as in NeoChord) the motion to dismiss the IPR came after the IPR had been instituted, ${ }^{24}$ and importantly after the state university had participated in the IPR. There are still some questions about applying the sovereign immunity defense, among them whether participation in a full patent infringement lawsuit waives sovereign immunity ${ }^{25}$ and whether tribal immunity (which has been ruled not to be a defense to IPR) and sovereign immunity are analogous for these purposes or not. ${ }^{26}$ But for now, sovereign immunity is a valid defense that state universities can use to defend their patent assets from IPRs.

Regardless of the outcome of the state sovereign immunity issue, universities still will only fund IPR defenses in only the most unusual of circumstances. In most cases, a challenger will only file an IPR over patents with proven economic value, which usually means after the patent's technology or science has been commercialized. Since the university does not commercialize patents itself, the patents ripe for IPR attack are almost always covered under license. The university license terms almost always mandate that the licensee cover the cost of enforcement, so even should the worst case IPR scenario happen, the university does not pay for defending its patent. So the cost of defense would only be an issue for the university under special circumstances - for example, if the patent at issue is unlicensed, or licensed nonexclusively such that no one licensee must bear the defense cost, or if the licensee could not afford the enforcement and the university wanted to step in to fund it.

For all these reasons, the reality of IPRs might have been expected to not match the hype. But I was curious to know if just the possibility of more IPR proceedings being filed has nonetheless changed how TTOs do business.

\section{B. TTOs reveal the effect of IPRs on filing, licensing, enforcement, and budgeting}

\footnotetext{
${ }^{22}$ Case No. IPR2016-01274, Paper 21 (PTAB, Jan. 25, 2017).

${ }^{23}$ Case No. IPR2016-00208, Paper 28 (PTAB, May 23, 2017).

24 Stephen Gardner, Nikia Gray, \& Bryce Loken, Patent Trial and Appeal Board Dismisses Second Inter Partes Review of University Patent on Sovereign Immunity Grounds, QUARLES AND BRADY LLP, May 25, 2017, https://www.quarles.com/nikia-l-gray/publications-and-presentations/patent-trial-and-appeal-board-dismissessecond-inter-partes-review-of-university-patent-on-sovereign-immunity-grounds/.

25 This question is at the heart of Regents of the University of Minnesota v. LSI Corp., case number 18-1559, on appeal to the United States Court of Appeal for the Federal Circuit, with arguments heard on March 11, 2019.

26 The case deciding against tribal immunity defense was Mylan Pharmaceuticals Inc. et al. v. Saint Regis Mohawk Tribe IPR2016-01127, -01128, -01129, -01130, -01131, -01132.
} 
After getting a general sense of the level of concern that TTOs had surrounding IPRs, and about how many IPRs they had experienced, I asked a series of questions to illuminate whether and how the possibility of IPRs had changed how TTOs were doing business, including whether they had changed their policies and procedures. I asked them to respond in four categories: whether IPRs had changed anything about their i) patent filing strategies; ii) licensing practices or results; iii) willingness to enforce their patents; and iv) budgeting. The answers to these questions are relayed below.

\section{1. "Have IPRs caused you to change your patent filing strategies?"}

Given the possibility of IPRs, TTOs might be tempted to refocus their patent filing, limiting filing to areas where IPRs are less common. ${ }^{27}$ They might also perform more exhaustive prior art searches during prosecution to potentially inoculate their patents against IPR challenge. However, the survey responses showed neither to be the case. TTOs were deeply opposed to the first idea, and they dismissed the second idea out of hand. However, some TTOs did suggest they are making subtle changes to their filing practices to attempt to ready their patents for IPR challenge.

Every TTO interviewed felt strongly that it was a critical part of their mission to protect all the patentable university inventions that might have a chance of being licensed and commercialized. They were therefore very opposed to making decisions on what to file or not file based on subject matter of the patent rather than on other factors. They were even somewhat offended at the suggestion:

We are fortunate because we are healthy financially, and we can act as the service organization we are and attend to faculty needs, and we can patent when the idea is protectable, as opposed to worrying about if it might be subject to an IPR.

We have money and resources and have always approached filings as more of a commitment to the technology transfer mission and less about tactics or profit margin. For us, when I picture 8 years ago, 2 years, ago and now-IPRs have not changed filing or licensing decisions.

TTOs hedge their bets best when they file at least provisional patents on every invention that has enough data to support an application. Because TTOs never know where the next great commercial success will come from and do not have enough information at the start of the process to understand whether a patent will become valuable, they say they would never pick and choose among fields merely on account of an increased risk of IPR.

Rather than avoiding certain subject matter to attempt to avoid IPRs, TTOs instead said they preferred to focus on ensuring that individual patent filings were as strong as they could be.

\footnotetext{
${ }^{27}$ Early reports stated that most patents being challenged (71.8\%) were in electronics and the computer arts. Berdine \& Rosenberg, supra note 2, at 17 (citing Christopher Douglas, et al., Inter Partes Review - One Year Later, AlsTON $\&$ BIRD LLP (Sept. 17, 2013)).
} 
For example, they file patents with as much supporting data as possible given publication constraints and first to file concerns. ${ }^{28}$ They avoid filing cover sheet provisionals whenever possible, and they make the claims of each provisional application as robust as possible. But they will also admit that these policies are not new. As one TTO explained, filing more complete patents is not a change brought about by the possibility of IPR, or even by the first to file provisions of the AIA, but is what TTOs have been trying to do for a while to protect their patents from attacks based on invalidity. The IPR and other AIA changes just make filing stronger patents even more of a priority:

I could see how some TTOs might use IPRs as a factor when looking at whether to protect computer inventions, etc. because those patents might be more susceptible to attack. Maybe you file less aggressively in that area. But it's rare that we make decisions not to file at all because of IPRs, both because we always file everything, and also because we have always handled all invalidation issues by just making sure the prosecution is as full as possible. IPRs haven't changed how we feel.

As to doing more prior art searching, generally, TTOs do not believe that more extensive prior art searches will inoculate their patents from IPR challenge. First, since the patents they file are over such early-stage technology, the likelihood of there being any other prior art knocking out the patent on newness grounds is already low. And should the prior art exist, the fields of invention are so insular that the inventors would likely already know about any other potential prior art. And although it is not legally relevant, some TTOs depend on professional journals' high standards for publication to give them insight into nonobviousness considerations. Since the TTOs are also generally strapped for resources, given the probable low risk of prior art citations, and given that some TTOs are worried about the results of a prior art search or a freedom-tooperate opinion ("FTO") being discoverable, TTOs are not shifting to expend more money on prior art searches. Unless IPRs become a more pervasive problem for TTOs, this is unlikely to change.

Further, the TTOs argue that not only would it be near impossible to judge which patents would be more vulnerable to IPR attack based on subject matter, but to make judgments about what to patent based on that analysis would be extremely unwise. They state that the better goal is to focus on filing inventions that will lead to strong patents, where there is (as best they can tell) a market to be licensed and commercialized.

Standard operating procedure on how we evaluate IP is based on whether the invention as disclosed has good potential market value. It ends up being a much bigger question than patentability. Our budget is small —we can only afford to protect what has good prognosis for market. We look at what the tech is, who the players are in the field, what the product would be under the invention, whether it is something based on market research that people are likely to buy. A lot of black magic really-you do your best to figure out what the market would be. If it looks like a problem recognized in the field and that people would buy it, then we file a provisional. Then we market to companies we identify and others, or if it's good tech for a startup, we license there. If there's no interest at all, we might recommend not to pursue the non-provisional. Or sometimes we

\footnotetext{
${ }^{28}$ Although this may not be as helpful in an IPR setting, because IPRs are based on Section 102 and 103 challenges, which are countered best by early filing.
} 
might think we have early technology, and the market is not ready; if we really think it could be important in market, we might file [a non-provisional application] anyway even without interest.

TTOs also make the valid point that they would never want to entirely avoid the risk of an IPR challenge by shying away from filing a patent that they think might be commercially successful. The patents that might attract an IPR are exactly the patents that TTOs should want to prioritize filing. Since there is a positive correlation between risk of IPR and commercial success, TTOs may favor filing the patents that might end up being most IPR-worthy.

Frankly, anything that makes it to the commercialization stage, you are going to get IPR'd. We will deal with it when we get there - there WILL be an IPR. The likelihood of IPR is going to be based on whether [the patent] has commercial potential, not on the strength of the patent. Regardless of what's been filed or not filed, they will attack. [IPRs are] like inventorship issues. When tens of millions of dollars are at risk, this [IPR] is just another tool.

Rather than the risk of IPR, when choosing which patents to file, TTOs are influenced much more by their concern over whether the patents will issue, given confusion around patentable subject matter and changes under the AIA that broaden what constitutes prior art and disclosure. TTOs describe IPR as being so sufficiently "downstream" that changing filing strategy based on a worry about IPRs seems a luxury when the patent will conceivably face so many challenges before it will even issue:

We base our filing decisions on prior art, the path to patent, but because we have limited budgets, we can't do a detailed patentability analysis. An IPR is so downstream, it doesn't impact the upstream decision on what to patent.

For the most part, we don't really think about IPRs that much. We think about allowance and validity, but not specifically IPRs. . . . Definitely feels like we are doing more provisionals, just to get that priority date, and preserve the international rights. . . . It is not IPRs that are pushing us - we don't think of it as that - tend to think about it as good prosecution. [IPRs are] just one more thing that we consider when we enforce and when we have our patents granted.

In sum, the risk of an IPR does not guide which patents TTOs choose to file. In fact, TTOs might be happy to have a patent in the portfolio that someday is deemed IPR-worthy, because it would be a strong patent with commercial value that is worth enforcing and challenging.

The one change in some TTOs' filing strategy is not about what patents to file, but tactically how to maneuver during prosecution. Borrowing from corporate practice, some TTOs are now filing multiple continuations for some of their most valuable patents, or splitting claims across several patents to keep a set of patent claims alive. These claim sets are then able to be revised as necessary if challenged through IPR: 
Universities file very early in the product life cycle and the patent process; it's really hard at that early point to position yourself against IPRs, so relying on continuations helps somewhat. If there were no IPRs, we would have a much thicker claim set. Continuations allow more flexibility to address the IPR; you can pivot to other claims to avoid the argument, if you keep the [patent] family alive.... With IPR, we now take a better look at continuation practice. We used to file continuations much more sparingly.

This is of course not an option for every TTO, and certainly not an option for every patent family or even most families within a TTO's portfolio. But continuation practice might be one helpful strategy to guard against challenges to patent validity, including but not limited to IPRs. This gives a patent owner a chance to fight back against what many consider a system that is slanted toward the benefit of the challenger. As one TTO stated: "Others are also doing the same thing in industry - we are taking their lead [in] that there are things you can do to protect yourself."

2. "Have IPRs changed your licensing strategies?"

The threat of an IPR might undermine the value of patents, which might carry over to patent licensing negotiations. On the other hand, depending on whether it is upheld, the state sovereign immunity defense to IPRs might shift the balance of power back in the other direction, since at least public universities might be able to offer a shield to the patents they license. If public universities can wield such a defense, that might in turn incentivize would-be licensees to license from public universities rather than their private university counterparts. All of these changes brought about from IPRs might conceivably force TTOs to alter their licensing strategies.

TTOs do report that licensees' attitudes toward patent value have in fact shifted. As a result, some TTOs are tweaking their licensing strategies around the margins to compensate. However, most of the TTOs attribute the shift in attitude more to their potential licensees' business models than to IPRs, especially as concerns patents in the physical sciences. And while a state sovereign immunity defense seems helpful in theory, the reality is that it has not yet conferred a licensing advantage on public universities, or even tended to affect licensing discussions much at all.

i. Some licensees' assessment of patent value has shifted, although probably not as a result of IPRs

To start, most of the TTOs believe that attitudes about patent value have shifted. Some of the shift is blamed on IPRs, although most of the evidence for that connection appears to be anecdotal and second hand:

We heard from other ... campuses that prospective licensees can threaten to launch an IPR if they can't get good terms as a negotiation tactic - this is awful! Whenever you start off a negotiation and someone is approaching it in such an aggressive way, it probably won't get better as you go on! But we haven't dealt with IPRs too much. 
There's a lot of talk too about how high-paying licensees already paying royalties might file IPRs to get out of their license, but we have not found that to be the case.

But most of the blame should not be placed on IPRs. TTOs surmise there is a connection between how much value a licensee confers on the patent and why the licensee is seeking to license the patent in the first place:

IPRs have impacted our ability to do business with established well-resourced businesses - they now increasingly look at IP through a slightly different lens. They look at assets as being helpful if they create an exclusive niche in the market, but if they are licensing just to prevent infringement, they are much less interested. It is even worse now, because they have a cheaper route to push back with IPRs. It has changed their perspective on the need to secure the patent, especially in the context of a freedom to operate.

So licensees that are hoping to sell a product based on the patents value those licensed patents more. Although IPRs are making a situation worse, perhaps only this certain subset of licensees - those that intend to commercialize the patent they are licensing - are really hoping for the patents they license to hold long-term value. Licensees that license in order to clear a freedom to operate hurdle do not mind if a third party challenges the patent they have licensed. Should the patent be proven invalid, provided the license allows termination upon such a finding, they can stop paying license fees. ${ }^{29}$ Since a sizeable percentage of the pool of licensees falls into the "freedom to operate" category, this could contribute to why licensees tend not to consider IPR risk when deciding whether to license and for how much.

In addition, TTOs believe that licensing has become more difficult because in certain industries patents hold less value than in others. While a patent can serve as the entire basis for a life science company's value, in the physical sciences, one patent is far less valuable. As a result, TTOs report that companies in the physical sciences industries tend to want to wait to be sued before they license a patent. Given that physical sciences companies create products that each could contain dozens if not hundreds or thousands of patents, infringement of any one patent (particularly a university patent which could be very early stage) is hard to prove, and since licenses to those patents tend to be nonexclusive anyway, a physical sciences company may make the decision to infringe rather than license:

It is more common to have [licensing] problems in the physical sciences than in life sciences. This is because most deals in life sciences are exclusive licenses, which carves out a niche. In physical science, it is much more about cross licensing, not an exclusive license. ... It is not universal in the physical sciences, but especially in electronics, we

\footnotetext{
${ }^{29}$ This assumes that the challenger is a third party. Many TTOs have provisions in their licenses that either terminate the license should the licensee challenge the patent, regardless of outcome, or keep the license active but automatically double or treble the license fees.
} 
are usually offering licenses to incremental tech in areas where they already have a foothold. They are just not that interested in licensing.

A lot of large companies now seem to have a blanket policy not to license. [IPRs are] possibly part of it, but more probably it's an aggregate lessening of value for patents. It is near impossible for us to get an injunction. It is hard for us to get large damages. Physical science companies are also getting savvy about whether patents matter to their industries. They have many more patents in any one invention, and the patents are over incremental changes. The perception might be different maybe for life sciences, but physical science companies are taking the risk- "come and get me."

All of these reasons add up to why many licensees of university patents may not ascribe as much value to the patents as they should. This has very little to do with the possibility of IPRs.

ii. Some TTOs have compensated for the reluctance to license through portfolio licensing and careful pricing

Given that many TTOs are not willing or able to enforce their patents against infringers (for a variety of reasons discussed more in the next section below), this new reality of "efficient infringement" challenges TTOs to develop new licensing strategies. One inventive responseespecially in the realm of the physical sciences - is to group patents together into portfolios to facilitate simultaneous patent licensing (especially in conjunction with enforcement after a patent has been infringed). This model acknowledges the reality that it is possible to build a life sciences company around licensing one particular patent, but that for a physical sciences company, licensing a portfolio of patents might be more enticing or even necessary:

The licensing models for the two departments (medical school and engineering school) are different. For example, a small molecule patent—you can build a company around it - it is easier to commercialize. But engineering improvements are smaller; you wouldn't build a company around them. We can get more revenue from a medical school patent because it is easier to build a company, easier to commercialize around it. It is more challenging for an engineering company. To deal with this, our new model is pooling engineering patents into a group and licensing as a group. We create a patent pool and license in a bundle.

It would be great if we [life sciences licensing officers] could get a portfolio, but in [another licensing officer's] space, it is much more of a concern. He works in magnetic resonance and wireless communications, and he is developing portfolios that he doesn't just proactively license, it's [also] ... a litigation play.

And in addition to licensing portfolios of patents, TTOs are also carefully considering the point of view of more reluctant licensees when they price their royalties. Especially in the physical sciences where the perceived risk of enforcement is low, and especially when the licensee is interested in licensing in order to get freedom to operate, TTOs are looking to hit a "sweet spot" that is low enough that the licensee is still willing to pay to close off all risk of infringement: 
We do proceed with greater sensitivity in that we have modified what we would ask for in license fees. If the fees are too high, particularly in an FTO [freedom to operate] license situation, that raises the risk of IPR. We try to hit that sweet spot - especially with FTO-where we want them to pay just enough. Too much, and they may challenge the patent.

In this way, TTOs are trying to meet the licensee where they are, changing their policies somewhat to accommodate. But this has much less to do with IPRs than with the needs and expectations of the particular licensees.

iii. The effect of a sovereign immunity defense to an IPR is still uncertain, but so far it seems to be only minimally relevant as a negotiation point

Is the prospect of sovereign immunity as a defense to IPR a valuable negotiation point for universities? When the Covidien case ${ }^{30}$ was first decided, TTOs of some public universities assumed not only that their patents could be shielded from this attack on validity, but that the shield could prove a valuable negotiation point with future licensees. Assuming the sovereign immunity defense could be imputed over to a licensee, ${ }^{31}$ the licensed patents could be completely inoculated from at least one form of attack. The public universities were not the only parties discussing this possibility; various commentators were mentioning the issue, ${ }^{32}$ and there was also a lot of industry buzz:

Something that has gotten a lot of attention — not so much made an impact, but gotten a lot of attention - is around the sovereign immunity cases, where public universities are immune from IPRs unless they sue first. . . . Some journalists were calling, law firms were offering congratulations, and the general counsel told us we might expect some attention.

Private universities also took notice. If IPRs were going to have a big effect on patent values and therefore on licensing success, a defense of sovereign immunity to IPRs could prove to be very important. The fact that only some TTOs could take advantage of the defense was a bit troubling, since it might also have created an imbalance in the community. But overall, although TTOs noted that any possible defense against IPRs would be helpful, they did not expect that sovereign immunity was going to be a driver for more successful licensing.

For one thing, an IPR is only one method to invalidate a patent, and other methods are not subject to the defense.

\footnotetext{
${ }^{30}$ Covidien LP v. University of Florida Research Foundation Inc., Case No. IPR2016-01274, Paper 21, (PTAB, Jan. $25,2017)$.

${ }^{31}$ This is an undecided question. As held in Reactive Surfaces Ltd, LLP v. Toyota Motor Corp., No. 1:14-CV-1009LY, 2015 U.S. Dist. LEXIS 106796 (W.D. Tex. Aug. 13, 2015), a sovereign immunity defense cannot be imputed over to a patent co-owner; in that case, an IPR was allowed to continue against the co-owner even as it was dismissed against the state university. However as of this writing, it has not been decided in court if a licensee can be protected from IPR by virtue of the licensor state university's sovereign immunity.

32 See, e.g., Gardner, Gray, \& Loken, supra note 24.
} 
Even without the IPR process, there are still ways to invalidate a patent; [sovereign immunity] doesn't foreclose the opportunity to invalidate, it just changes litigation strategy. IPR is still a strong tool, so [the defense] is still worth something, but not so much. . . . In a nutshell, being able to foreclose an IPR option is helpful (valuable) but not dispositive.

In addition, the case law around sovereign immunity and IPR is still developing. There are many untested aspects of the sovereign immunity argument that may undermine its power as an IPR defense. ${ }^{33}$ For example, although sovereign immunity clearly applies to state universities as patent owners, it might be a personal defense. ${ }^{34}$ It is less sure that sovereign immunity can be commuted over to protect the licensee of a patent owned by the state university. It is also not sure that sovereign immunity applies at all when the TTO is a nonprofit entity affiliated with a state university (as is the case with the University of Wisconsin) rather than an arm of the state university itself. Also untested is the question of when and under what conditions the state university loses whatever sovereign immunity defense it had; for example, whether the university loses its defense if it proactively files suit against the challenger for infringement. ${ }^{35}$ And finally, in a recent case, the United States Court of Appeals for the Federal Circuit ("CAFC") determined that tribal immunity did not apply to shield a patent from an IPR proceeding. ${ }^{36}$ Although the state university TTOs can distinguish their missions easily from that of the Native American tribe in question in the case, that case might be seen to represent a weakening of the sovereign immunity defense in general. All of this uncertainty could undermine the value of the defense as a bargaining chip. In particular, should the state sovereign immunity defense be waived once the university files suit against the infringer, then the defense is worth less to the licensee, who can only use it so long as he does not enforce the patent.

So at the PTAB, sovereign immunity can be used as a defense. But if you file suit, you waive those rights (potentially). So it becomes a difficult sell as a bargaining chip-you can't bring suit, so how is it a good defense?

Sovereign immunity might also be inapplicable to any one license situation because it might not be possible to choose between licensing opportunities. Most technologies are unique to the university. While a defense of sovereign immunity offered by a public institution might be compelling, if the technology the licensee needs was created at a private university, that is where the licensee will execute the license. As one TTO explained, different offices are not necessarily in competition with each other. Licensees will license the patents that they think they can commercialize, regardless of who owns them:

\footnotetext{
33 Sovereign Immunity Growing as Inter Partes Defense, Effect on Licensing Terms Unclear, 11 TECH. TRANSFER TACTICS 7 (July 2017), https://www.quarles.com/content/uploads/2017/07/Technology-Transfer-Tactics-July-2017Reprint-Sovereign-Immunity.pdf.

${ }^{34} I d$. (citing interview with Dan Venglarik).

${ }^{35}$ In Ericcson v. Regents of the University of Minnesota IPR IPR2017-01186 -01197 -01200 -01213 -01214 -01219, the PTAB denied the University of Minnesota's motions to dismiss the pending IPRs on sovereign immunity grounds because U. Minnesota had sued Ericcson for patent infringement. This case is pending on appeal before the CAFC.

${ }^{36}$ Mylan Pharmaceuticals Inc. et al., supra note 26.
} 
We don't think about other universities as our competitors. If you want our tech, license. You might not be able to get the same tech somewhere else. CRISPR is at X-if you want it, go there. When a company looks at three competing technologies, they are not deciding on who offers the best deal, and even if they choose the best deal, it is probably not about the IPR. It's about "can they commercialize or not?"

And finally, since IPRs only come into play later in the life of the patent when the technology has become a successful product, for licensees, potential defenses to IPRs may seem very distant and at the very least lower in priority. The chance of IPR seems so far removed from the present that IPRs are not on the minds of even the savviest and most forward-thinking licensee. As TTOs explained, most licensees are primarily focused on whether the patent is going to grant at all:

IPR does not drive [licensing] —I haven't heard a licensee say, "we would like to partner with you, but we are concerned about withstanding a challenge." Much more the question-“is this thing going to issue?"

IPR is typically not an issue unless you are dealing with an exceptional patent that is productized. It is not high on the list of priorities for a licensee, because IPRs only hit when the patent and product are hot.

And as TTOs from public universities hungry to use sovereign immunity as a selling point say is a sobering thought, most of their licensees do not even know what an IPR is, let alone how sovereign immunity might defend their patent asset. A large percentage of TTO licenses are executed with start-up companies, which are often unrepresented or have counsel that do not know much about IP. And even if they know that IPR can affect their patent's value, often smaller companies are licensing their own inventions back from the university, so they are confident in the newness and nonobviousness of their invention. They view licensing as a means to a commercialization ends rather than an investment in the value of the patent. As a consequence, the sovereign immunity defense does not seem relevant to them. Far from being a differentiator, in a license negotiation, TTOs are finding that licensees do not even understand the concept:

But in reality, startup licensees are not even thinking about substantive rights when they license - they are thinking: what does investor want to see, and what will help me make money. It's almost as if the licensee is checking the box. Do they have the ability to practice and a clean chain of title? They might not actually look at the patents, let alone get into the weeds of the rights.

They are small companies - they don't understand patent law and how it works - they understand they need patents, but don't understand the sovereign immunity or IPR process or what that means. It is surprising to find that small company licensees just aren't very sophisticated regarding IP and don't use outside attorneys, and even if they do, those attorneys don't understand IP issues. I was surprised when I came-coming from large pharma, I was used to people that understood IP. With these little companies it doesn't seem to have as much value. 
In sum, public university TTOs report that they will sometimes bring up the concept of IPRs and a sovereign immunity defense to IPRs. But the topics are seldom brought up by the licensee, and never become important to bargaining in the license negotiation. Licensees will occasionally question patent value, but that negotiation point is more focused on whether a patent will issue, and its value to overall commercialization. Public universities may hope that the sovereign immunity defense to IPR will take on greater importance in the future, potentially as licensees become more aware, and the case law settles. But for now, sovereign immunity has not resulted in additional licensees, nor sparked more successful negotiation results.

We have never had a person bring that up. It's a theoretical argument, like we are usually playing checkers with licensees and this argument is from 3D chess. Licensees have to have a lot of things in a row, they are thinking about a lot of stuff. [An IPR defense] would be a lot to consider.

I haven't seen any budge in licensing, but $90 \%$ of our licensees probably have no idea about that aspect of the law. It's a pretty rare case that we are licensing to a sophisticated and large entity.

The big name companies probably [understand]. But there could be a disconnect between their business development folks and their legal team. I am not sure that the awareness of legal has percolated. Similarly, we are aware of the issue, but we haven't brought it to the forefront of strategy in our business dealings. I have heard other speakers at conferences mention that third parties have raised the issue with them in meetings. I wouldn't be surprised if it came up in the future for us.

I have talked to some licensees about sovereign immunity issues. Having IP in the name of the university rather than in name of licensee if we are doing a sponsored research agreement might be helpful to them. Mostly have [only] used it in the negotiation, but I am not sure of the effect of it. Some licensees still insist they have to own the IP no matter what - some say they want to jointly own. So [sovereign immunity] is probably not instrumental in completing deals, but we are bringing it up.

iv. Sovereign immunity is similarly not driving any shift in business model

Because the defense of sovereign immunity could protect against IPRs, looking at the Saint Regis Mohawk Tribe facts for inspiration, it seems like there might be an opportunity for public universities to develop a cottage industry as a patent holding company. Since the Saint Regis case was narrowly construed to interpret tribal as opposed to state immunity in the context of an IPR defense, it might be possible for state universities to take assignments to third party patents in order to shield them from IPR attack. One TTO explained that they had in fact been approached, but that they refused to go down that path, based on a conflict with the TTO mission:

People [have] called me up asking to assign patents to [university] — I said no-we don't want to be in that business. Some faculty thought this was a good monetization idea. But 
our administration said no; we are for research and education. Our outcome is sometimes patents, and we will defend sometimes, but we didn't want to shift to this model.

So even if courts do not extend the Saint Regis tribal immunity holding to state sovereign immunity actors, TTOs reported they are not interested in shifting their licensing policies and procedures in this way.

v. IPR is causing some TTOs to redraft their licensing documents to ensure that licensees pay for IPR

One universal truth across the TTOs is that whenever possible, someone else should pay to defend against any IPR. This topic is discussed in more detail in the section related to budgeting below, but many TTOs have in fact changed their licensing policies in one way because of IPR: they have redrafted their license agreements to more clearly state that if a patent is licensed, the licensee is responsible for paying to defend any IPR proceeding. ${ }^{37}$

Most TTOs have both prosecution and enforcement sections in their license agreements. Many TTOs have added IPRs specifically to one or the other section, usually in a way where the licensee should front the cost for the defense instead of reimbursing for it. Although the TTOs realize that if the patent is licensed to a start-up company that they may not be able to pay that cost, like any other costs associated with litigation, the beginning bargaining position is that it will be the licensee's responsibility.

We had to adjust our licensing language - when we license to a company, we put the possibility of this expense under the "prosecution" section rather than litigation so that the company pays for it.

Generically licensee pays for all patent costs (directly or indirectly), so we assume that that includes IPRs. But we did add language after the AIA to explicitly call out the IPR process as being under prosecution.

Yes, we have changed the language in the prosecution section to cover IPRs as patentrelated expenses that the licensee is directly reimbursing. But we are also realistic — if [licensee is] not a big company, as soon as the expenses start to hit, regardless of what's in the contract, it's going to be an issue.

Some TTOs did not change their license language because they felt it was already sufficiently broad to cover IPR ("No changes to contracting — all locked up already."). But they

\footnotetext{
${ }^{37}$ Interestingly, forcing the licensee to fund the defense of an IPR can potentially set up a conflict of interest if the license is for freedom to operate purposes. It is likely that such a licensee may want the IPR to succeed, and thus may not want to defend it, if the IPR would invalidate the university patent and obviate the need for the licensee to pay license fees. David Schwartz, Universities Face An Increasing Likelihood Of Inter Partes Reviews, TECH. TRANSFER ENEWS BLOG, TEASDALE (Oct 8, 2014), https://techtransfercentral.com/2014/10/08/universities-face-anincreasing-likelihood-of-inter-partes-reviews/.
} 
were sure that the expense would be covered. One final TTO is waiting to change its license language to specifically cover IPR until the sovereign immunity cases are resolved. Because sovereign immunity might turn out to be a complete defense to all IPR challenges, this TTO did not feel ready to assume that any party involved with its patents would be responsible for funding the defense of an IPR.

\section{3. "Have IPRs changed your patent enforcement?"}

Since an IPR proceeding attacks a patent's validity and costs money to defend, TTOs might think twice about enforcing a patent, lest the enforcement attract an IPR. Especially because IPRs are most commonly filed against university patents that have been commercialized, through enforcement, the TTOs might be opening up their most valuable patents to potential challenge. The choice is further complicated by the fact that most of the time the patents that are enforced have been licensed to a third party, which controls and will pay for the enforcement. So although the patent is the university's asset, and the TTO will likely weigh in on the decision to enforce, it is the licensee that is calling all the day-to-day shots on the enforcement, and on defending any filed IPR.

The interviews revealed that most TTOs do in fact specifically consider the risk of IPRs when they consider enforcement, although some TTOs weigh the possibility much more heavily than others. One of the more concerned TTOs stated:

It used to be that if you believed there was an infringer, you could send a licensing request and at most risk a declaratory judgment, but you now risk an IPR. The financial barrier for a company [to file an IPR] is much lower than in litigation, so [IPR] is almost a certainty . .. [IPR is implicated in] a limited number of cases, but when it's relevant, it's very relevant.

As a result, at least one TTO reports they are extra careful during prosecution to make their "assets as impervious to IPRs as possible . . . meeting our duty to disclose, seeing that references get properly considered and things like that." However, even that TTO acknowledged that the standard is likely not that different from before because they "were always careful because patents could always be challenged." In addition, other TTOs bemoaned their quandary: they wanted to be able to file patents that could resist IPR, but one realized that they "can't do prior art searching for all of our applications; it's too expensive," and the other wisely stated that all patents remain vulnerable, especially university patents due to their early stage:

Inherent in how early you have to file, and how early the technology is, and how often people disclose before they file, university patents are vulnerable. . . We want to file the best patent, but we can't always. You can't control patent quality like you can in corporations.

Another TTO concerned about IPRs specifically consults with its licensees whenever it is considering enforcement, and specifically counsels them to guard against IPRs by running an extensive prior art search on the patent before taking any steps toward enforcement. They explain that this extra step is designed to find any art that was not discovered before and allow 
both the licensee and the TTO to more accurately assess the risk of losing an IPR attack on the patent.

However, these TTOs are in the minority. For the vast majority of TTOs, the risk of IPR is not at all an important factor as to whether they enforce their patent. The reasons are economic, cultural, and logistical. ${ }^{38}$ Simply put, for most TTOs, there are so many other competing and more important considerations that go into the analysis about whether to enforce a patent such that the threat of IPR does not significantly affect the ultimate decision.

First, TTOs execute a complicated economic analysis to decide whether it makes sense to enforce a patent against an infringer. IPRs are only a small part of that analysis, both because usually a licensee is footing the bill, and also because even if the university is paying, the IPR is only a small percentage of the whole. TTOs cited the relatively low cost of an IPR as compared to the total litigation expense. As one TTO stated, remembering the analysis it went through before enforcing a patent: "Given the costs of cases, the cost of IPR would still be relatively inconsequential ... We were well aware that IPRs were possible when we filed," and another TTO: "Is it a pebble on the scale? I suppose, but it is a pebble." For these TTOs, other concerns other than IPRs weighed much more heavily in the economic analysis. For starters, as one TTO reported, it must consider the unique challenges facing a university enforcement that make enforcement more difficult: since universities do not make and sell a product, an injunction is not a sufficient remedy for a university, and further, because the patents are so early stage and may be one of several patents being used in the infringing product, it is a riskier and more expensive proposition for a university plaintiff to prove infringement, let alone damages. TTOs attempt to consider all aspects of the case that may weigh into the overall chance of success, and the IPR may have only a small role to play:

Litigations are always a time and money sink. We have to evaluate whether [the whole case] is worth it on the merits, how long it will last, who the adversary would be, and whether we can come to a settlement agreement first. [We] always have had to do thisIPRs are just part of the analysis now.

The analysis of whether to enforce a patent is at least as much if not more about whether the patent is strong, valuable and infringed, and even the kind of technology the patent is over, than about the risk of IPR, even if losing the IPR means losing the asset altogether. The economic analysis is multifaceted and complex.

Beyond economic reasons, TTOs also must address cultural influences that prevent them from pursuing patent enforcement. Many TTOs claim that they face philosophical hurdles to trying to enforce their patents that take precedent over any risk of IPR as a deciding factor. TTOs confess a common institutional reluctance to enforce patents at all because of a real or perceived conflict with the TTO mission to simply protect and license (but not enforce against infringement of) inventions. For example, one TTO explained: "Every patent owner knows if you do not enforce sometimes, you have no credibility ... [but] our mission is tech transfer. The only time we would enforce a patent is when the technology is significant and widely practiced, and licensing overtures have gone ignored." Another TTO questioned whether enforcement is ever

\footnotetext{
${ }^{38}$ For an excellent discussion of the complex set of considerations behind a TTO's decision to enforce its patents, see Jacob H. Rooksby, When Tigers Bare Teeth: A Qualitative Study of University Patent Enforcement, 46 AKRON L. REV. 169 (2013).
} 
appropriate for a TTO, but also acknowledged that a culture of nonenforcement creates a tension that makes serving different constituencies difficult:

We have one case where we are exploring enforcement. There are bad faith facts, the inventors are worked up, so we have some buy-in to at least investigate. But that's not what we articulate as our mission. We are supposed to be about getting the technology out into the world. If someone is already using [the technology], is that mission accomplished? But our client is also a series of inventors - they want attribution, and the money means something to them; it is hard to tell them 'don't worry about it.'

Relatedly, TTOs also want to ensure that their actions uphold the good reputation of both the university and its inventions. Depending on the philosophy of the TTO, this can either mean no enforcement (if enforcement is seen to be counter to the university's mission) or stronger enforcement (so as to reinforce the integrity of their licensing and to show that the patents have value). The first approach is illustrated by this quote from an institution that does not often enforce its patents:

The issue is that [university name] doesn't want to go off and sue people. We often get requests to sue from our PIs [principal investigators]. We go through the motions, but we are just not going to send the mean letter. We at most are going to send the "Gosh, are you aware of this patent?" letter.

But another TTO has the exact opposite approach since they believe in stronger enforcement:

We are one of the highest [patent] filers in the nation. We have valuable IP assets with economic impact and a mission of developing IP. It is important we are seen to be protecting our IP. We don't want to be frivolous, and we don't pursue everything, but we need to maintain our reputation. IPRs are one of several factors we consider [when we enforce]; we want our patents to stay valid.

A final TTO summarized the tensions well:

[It's a] fine line that you walk-people have to know you would enforce, but you cannot go after everyone. We try to be fair; reputationally it's both about the strength of our patents and also about our conduct as partners and in the industry. And it's about our goals. We are not revenue driven, like a company. We are part of the university.

Finally, TTOs may not be considering IPRs heavily in their enforcement analysis because they are overwhelmed by administrative hurdles. The TTOs are only one part of the university. One TTO lamented that even when the case for enforcement was clear, the enforcement calculus was still complicated because it depended on the players involved: "the politics are hell; we might find ourselves suing a company that has a founder that will fund a [university] building." Another TTO discussed the many ways that the university was connected to the community and the inherent conflicts of interest that created: 
The TTO represents one aspect of the university, but not all of [university name]. You don't make friends this way [by enforcing patents]. There are donors, partners, etc. ... And overall, it's not like our office brings in more than the development office, so we have to listen to them. . . . If [an infringer] wants to give money to research or hire our students, we're just not going to do it [enforce a patent] . . Relationships are now far more complicated because students are going to work at [companies that are infringing our patents], they are starting their own companies, professors and alumni are on boards, it's a very complicated mine field you have to navigate. We have to be pretty positive about the validity and the strength of the patent and that someone's product infringes before we would consider it. . . . It is so much more complicated when you are a university rather than a corporation.

Before getting approval to file a patent lawsuit, TTOs often face layers of bureaucracy, such as getting sign-off from the highest levels of the university, or even of the state attorney general's office in the case of a public university (when a state university enforces a patent, technically it is the state that is the plaintiff and the case is funded by taxpayer dollars). As one TTO explained the process at her university:

You have to get it approved by the Office of General Counsel, you then go to a subcommittee of Regents who have to decide if it's a gamble worth taking, and litigation counsel might have to convince them; then you have to structure a fee schedule, possibly look at patent strength scores, evaluate who the defendant is. ... In sum, it's a last resort.

The analysis becomes even more complicated when the university is part of a larger system, where the possibility of a conflict multiplies across the many related schools. As a result, enforcement of a university patent is exceedingly rare and does not depend heavily on the possibility of IPR. Many of the TTOs interviewed did not think that their office had ever enforced a patent, and not one of the TTOs currently has more than four active litigations.

In sum, there are many conditions that go into whether a TTO enforces a patent. The possibility of IPR is one consideration that TTOs might keep in mind, but it is not near the top of the list.

\section{4. "Have IPRs caused changes to your budgeting?"}

Because increased risk often equals increased cost, the new IPR proceedings might be forcing TTOs to allocate money differently to ready themselves for any eventual IPR challenge. I asked the TTOs to consider whether they had changed their budgeting both to support new filing techniques designed to strengthen the quality of their patents, as well as to set aside money to address IPR defense, either within or apart from enforcement litigation.

Those who have implemented slightly modified filing policies to improve their patent quality at least in part because of IPRs, have modified their budgets accordingly. One TTO is paying for more continuation practice to keep claims alive should the need come to hedge bets on a patent under attack through IPR. Although continuations are not terribly expensive, this TTO has had to increase the budget for its patent filing. Similarly, another TTO is taking steps to improve the quality of its patents in the face of potential IPRs by sending its provisionals out to 
be drafted by outside attorneys, instead of handling all its provisional application filing in house. That university is filing fewer patents now, but also was able to reallocate the filing budget to accommodate the change in policy.

However, as to budgeting specifically for IPR defense, although some TTOs seemed to have some misgivings about it, not one TTO reported changing its budget to accommodate any additional risk presented by IPRs. Some specifically mentioned that they had not experienced enough IPRs to worry about allocating funds:

No-when we set our budget, we go through various questions about what costs may come up this year. ... An individual issue may cause us to adjust our overall budget for the year, but IPRs are not a separate line item. We don't anticipate them and don't budget for them because we haven't had many.

The consensus across the TTOs is that budgeting specifically for IPR defense is unnecessary given that the risk of exposure was so low. They cite that a rare set of circumstances would have to occur for an IPR to be filed. TTOs also complain that they barely have enough money to cover the cost of the necessary patent filings they hope to do within the office. Although they might like to have some money put aside for IPR emergency or for any sort of enforcement, they are already barely meeting their current costs:

I've been thinking about a buffer-do we need one? If a patent is valuable, should we have a war chest - to enable us to go after a third party if needed? For example, if a licensee says we don't owe you a royalty, because we are not using the patent any more, we have no budget to make this inquiry. We don't have money set aside to do this. We haven't even progressed to asking where [that money] would come from! I've been with the office for 13 years, and our budget has been essentially the same. We pay all costs for licensed and non-licensed patents. To think about a reserve is hard when we don't even have enough [money] to patent.

Besides the low risk of occurrence, TTOs also explain that they have decided not to budget for IPRs because in most cases the university would not be responsible for funding the defense. Since most IPRs occur against licensed patents, TTOs assume that in most cases the licensee - not the university - will have to pay for the defense. And even in the smaller set of situations where the university would be responsible for paying, such as when the IPR challenges an unlicensed patent, a patent is nonexclusively licensed to several parties (such that any one licensee is not responsible for paying), or when the licensee cannot afford to defend the patent, the TTOs can rely on traditional as well as possibly some new options to finance the defense. One TTO described her relationship with a law firm on a fee arrangement that has helped with — and even encouraged — enforcement over the past ten years:

Occasionally the firm has done some evaluation of some patents, has come to us proposing enforcement. That's how these last two cases came about. We convinced the licensee to go ahead with enforcement. We may decide to do a few others.... As a whole, the university is risk averse in terms of IP; they try to have relationships with companies, try not to sue those we have relationships with. ... But coming from industry, 
I feel you should enforce. It is a way to get value out of your patents if you can't license. Frankly we have a lot of patents on the books just sitting there.

And other TTOs explain a new model for financing enforcement and IPR defense that involves a separate litigation financier providing the money for the proceedings:

The universities generally don't fund the litigation themselves; they look for a law firm on contingency, or they engage with a litigation financier. There is more of that happening in the industry. It is expensive, but these are investment firms investing in IP through financing the litigation. It is basically debt financing; they advance the money for the litigation. If it is successful, they recover a multiple of what they fronted (through damages after the university pays back expenses) and then a percentage of a share of royalties going forward.

Several TTOs mention the litigation financier option as possibly increasing TTO willingness to enforce patents (and defend against IPRs) because it erases the stigma of working with a contingency law firm and "feeling like a troll." ${ }^{39}$ Because under the financier scenario the TTO can choose to work with its preferred law firm and control the litigation, it may allow TTOs to enforce their patents in a way that feels more within the mission of the university. In fact, these firms seem to be specifically targeting universities as a viable option:

What's my budget for enforcement? Zero. None. But we almost don't need it; litigation funders are a pretty big part of the litigation scene now. They are like VC [venture capital] firms sitting on funds and [they] will buy a piece of litigation. You hire the firm, they will pay the fees, in exchange for $40 \%$ of revenue. This is available to universities. A lot of these firms were at AUTM [annual conference of the Association of University Technology Managers] to pitch their services.

Should working with a law firm or a litigation financier not be possible, the TTOs explain that they would have to take those situations as they come. Each describes a process whereby they would analyze whether it was worth defending the challenged patent, and if so, where they would go to request funding. One TTO surmised the extra funding would come from litigation funding the TTO always receives from the home school of the affected patent; another TTO said it would seek funding thorough the general counsel's office that would be allocated by a committee, and several said that they would have to find the money elsewhere in the TTO budget or from a different university department:

I do think about it—what would we do if and when IPR were to happen? We would look at the status of the case - how much is it worth it to us to fight. For each case we analyze risk - we consider whether we file overseas, divide the patent, etc. There is always a cost benefit analysis. So we would look at all facts - how old is the patent, what is its track

\footnotetext{
${ }^{39}$ See Rooksby, supra note 38, at 187-191 (discussing how hiring contingency law firms - as opposed to litigation financiers - feels more "like a troll" to certain TTOs); see also Jacob H. Rooksby, University Involvement in Patent Infringement Litigation, 47 LES NOUVELLES 8, 17 (2012) ("However, some technology transfer professionals who indicate their university has engaged law firms on a contingency fee basis in the past have stated they view these risk-sharing arrangements as perilous or even inappropriate for universities to accept.”).
} 
record of licensing, is it a slow market that will be important even if not yet important. . . . I have a hunch that if they are filing an IPR [especially if outside a litigation], it is probably an important patent. If it is that important, we probably would find money to manage the cost. We would reach out to the university to support the effort, or reallocate some costs.

Regardless of the ultimate decision, TTOs — at least at this stage — are content to maintain current budget policy and wait to deal with an IPR defense only when and if the problem should arise.

\section{What does the future hold for TTOs contemplating IPRs?}

Even though it has been more seven years since the IPR procedure was implemented, the effects of IPRs have not been what might have been expected. Whether by virtue of the earlystage technology that TTOs patent, their philosophy of limited enforcement, or use of a structure whereby patents that are commercialized are usually licensed, TTOs have not yet had to systemically change their filing, enforcement, licensing, or budgeting policies to accommodate IPRs.

But the TTOs I interviewed were withholding judgment about what the next five years would bring. Looking forward, there may be changes in case law that would encourage TTOs to react. Although IPR proceedings do not yet drive TTO decision making, case decisions could still settle uncertainty and give TTOs finality on how to proceed.

For example, even as sovereign immunity is not providing much of a licensing advantage to public universities yet, it would still be efficient to resolve the uncertainty around its applicability. Knowing at what point the state university patent owner waives the sovereign immunity defense because of involvement in a litigation proceeding will definitely help plan litigation strategy for even the few numbers of enforcement proceedings going forward. Similarly, it is hard to use sovereign immunity as a bargaining chip in a licensing negotiation if it is not clear if the defense can shield the patent licensee. TTOs should continue to monitor IPR cases until that question regarding licensees is resolved. It will be interesting to see if the CAFC's decision on tribal immunity will have implications for state sovereign immunity cases. ${ }^{40}$ And finally, there are still questions left open by Oil States about the constitutionality of IPRs under the Due Process and Takings clauses, and whether IPR should be able to apply to patents that issued before the AIA. It is not inconceivable that the CAFC or even the United States Supreme Court might have to consider those questions in the terms ahead. Even though IPRs have not affected TTO policy significantly, it would still be a relief if IPR proceedings were completely shut down on constitutional grounds.

TTOs must also keep informed on executive branch and legislative activity related to IPRs. The PTAB is now grappling with how to retroactively apply the results of SAS Institute to IPRs that were incorrectly decided. This holds huge implications for the few IPRs to which TTOs are party, as to whether the PTAB needs to consider the additional claims, and what the estoppel effect of these IPR decisions will be on any infringement lawsuits. In addition, USPTO Director Iancu has been outspoken about the IPR process, and he acknowledges that industry blamed IPRs and associated uncertainty about patent value as contributing to the US falling from

\footnotetext{
${ }^{40}$ Or if in fact the case may be overturned. As of this writing, the case is on petition for certiorari with the United States Supreme Court.
} 
first place to twelfth on the United States Chamber of Commerce annual Global IP Index patent list from 2017-2018. ${ }^{41}$ Following Director Iancu's announcements that he would like his office to focus on "increasing the reliability of the patent grant," specifically addressing IPR proceedings, hoping to "balance rights-holder's and rights challenger's interests," 42 which led to the USPTO rulemaking that harmonized standards of review between the PTAB and district courts, in 2019 the US returned to a second place ranking. ${ }^{43}$

IPRs have also caught the attention of Congress. Legislation introduced in 2018 in the House, with a parallel bill reintroduced in the Senate was designed to address some of patent owners' most salient criticisms of IPR proceedings. Its sponsors are hoping to reintroduce the bill in the 2019 Congress. Entitled the Support Technology \& Research for Our Nation's Growth and Economic Resilience ("STRONGER") Patents Act of 2018, ${ }^{44}$ the bill, among other things sought to: align the PTAB and district court claim construction and burden of proof standards; impose a standing requirement to bring an IPR; give deference to prior court adjudications of validity and limit the number of challenges that can be brought against the same patents and claims; allow a patent owner to more easily amend claims during an IPR; and create separate panels of judges to decide on instituting an IPR and ruling on the merits. The bill also addressed a few issues to make infringement lawsuits easier to file and win, namely revising the standard for inducing infringement, making it possible to infringe even if manufacturing of infringing product occurs overseas, reinstating the presumption that an injunction is appropriate if a patent is found valid and infringed, and giving the Federal Trade Commission the authority to file suit against parties that send demand letters issued in bad faith for purposes of extortion. Some form of this bill has been introduced for several sessions. Congress is responding not only to the numbers of invalidations, but also to some egregious misuse of the IPR system, as with hedge fund managers like Kyle Bass shorting stocks of biopharmaceutical companies and then launching IPRs to drive stock prices down. ${ }^{45}$ If IPRs continue invalidating patents at the current pace, and the numbers of IPR proceedings stay high, and stories like what is happening with Kyle Bass continue to pique the interest of Congress and the public, the legislation may gain traction. ${ }^{46}$

\footnotetext{
${ }^{41}$ U.S. Chamber International IP Index, Global InNOVATION POLICY CEnTER (6th ed., Feb. 2018), at 35 http://www.theglobalipcenter.com/wp-content/uploads/2018/02/GIPC_IP_Index_2018.pdf.

42 Andrei Iancu, Director, at U.S. Chamber of Commerce Patent Policy Conference (Apr. 18, 2018), https://www.uspto.gov/about-us/news-updates/remarks-director-andrei-iancu-us-chamber-commerce-patent-policyconference.

${ }^{43}$ U.S. Chamber International IP Index, Global InNovation Policy Center (7th ed., Feb. 2019) https://www.theglobalipcenter.com/wp-content/uploads/2019/02/023593_GIPC_IP_Index_2019_4Pager.pdf. ${ }^{44}$ H.R. 5340, 115th Cong., https://www.govtrack.us/congress/bills/115/hr5340 (last visited Mar. 28 , 2019). Analysis of its salient points is at Steve Brachman, STRONGER Patents Act Introduced in House, Seeks to Strengthen Crippled Patent System, IP WATCHDOG, Mar. 28, 2018, https://www.ipwatchdog.com/2018/03/26/stronger-patentsact-house $/$ id $=95188 /$.

${ }^{45}$ See Gene Quinn, Post Grant Patent Challenges Concern Universities, Pharma, IP WatchDog, Apr. 1, 2015, https://www.ipwatchdog.com/2015/04/01/post-grant-patent-challenges-concern-universities-pharma/id=56351/. ${ }^{46}$ Many of the ideas set forth in the STRONGER Patent Act have been suggested separately by commentators as being good for patent owners and specifically small businesses. See Melissa Cerro, Navigating a Post America Invents Act World: How the Leahy -Smith America Invents Act Supports Small Businesses, 34 J. NAT'L Ass'N Admin. L. Judiciary, 225, 226, 229 (2014); Neal Solomon, Solutions for Inter Partes Review: Restoring Patent Rights and Respect for the Presumption of Validity, IP WATCHDOG, Aug. 10, 2017, https://www.ipwatchdog.com/2017/08/10/solutions-inter-partes-review-restoring-patent-rights-respect-presumptionvalidity $/ \mathrm{id}=86680 /$.
} 
IPRs have transformed the patent litigation landscape. They will conceivably continue to play an important role for years to come. Although survey answers confirm that IPRs have not yet affected technology transfer to the point where TTOs must make significant policy changes, IPRs are an important consideration as TTOs make decisions about how best to fulfill their missions. TTOs should continue to follow the latest court decisions and executive and legislative proposals on IPRs. At some point IPRs may become a more significant part of the TTO landscape, particularly if shifting ideas about patent value, licensees with different licensing needs and philosophies, and new limits on patentable subject matter force TTOs to grapple with broader visions of mission that encompass increasingly more patent enforcement. 